\title{
A difusão do Orçamento Participativo brasileiro: "boas práticas" devem ser promovidas?
}

\author{
Brian Wampler \\ Boise State University
}

\begin{abstract}
Resumo: A "terceira onda" de democratização foi acompanhada pela proliferação de novas instituições, que permitem aos cidadãos deliberar e decidir sobre o resultado das políticas adotadas. Organizações internacionais de prestígio, como o Banco Mundial e as Nações Unidas, disseminaram programas de "boas práticas", associados a esforços de reformar políticas apoiadas na idéia de "boa governança". Um dos programas mais conhecidos, o Orçamento Participativo (OP), foi adotado pela primeira vez pelo Partido dos Trabalhadores (PT) no Brasil em 1989, como forma de promover justiça social, responsabilidade e transparência. A adoção do orçamento participativo no Brasil se ampliou, capitaneada pelo partido. Não obstante seu pioneirismo, por volta de 2001, quase a metade dos programas de OP haviam sido adotados por governos de outros partidos. O que pode explicar por que governos municipais no Brasil, em especial governos de outros partidos, adotaram programas de OP? Este artigo procura avaliar a probabilidade de que um município adote o OP, recorrendo à análise de regressão logística para testar um modelo que inclua variáveis eleitorais, econômicas, regionais e de redes de políticas públicas. Na conclusão, avalia-se concisamente se os governos que adotam o OP são capazes de produzir resultados similares aos resultados iniciais que inspiraram a designação de "boa prática", o que leva a enfrentar a questão: sob que condições a eventual adoção de programas de "boas práticas" deveria ser promovida?
\end{abstract}

Palavras-chaves: difusão, democracia participativa, políticas públicas, orçamento participativo, Brasil.

\begin{abstract}
The "third wave" of democratization has been accompanied by the spread of new institutions that allow citizens to deliberate and decide policy outcomes. Leading international organizations, such as the World Bank and the United Nations, have disseminated "best practice" programs identified with "good government" policy reform efforts. One of the most well-known programs, Participatory Budgeting (PB), was first adopted by Brazil's Workers' Party (PT) in 1989 as a means to promote social justice, accountability, and transparency. There has been widespread adoption of PB in Brazil, led by the PT. Yet, by 2001, nearly half of PB programs had been adopted by non-PT governments. What explains why municipal governments in Brazil, especially non-PT governments, would adopt PB programs? This article estimates the probability that a municipality would adopt PB using logistic regression analysis to test a model that included electoral, economic, regional, and policy network variables. This article concludes by briefly analyzing whether governments that adopt PB are able to produce policy outcomes similar to the initial results that inspired the "best practice" label. This introduces the question: When should best practice programs be promoted for possible adoption?
\end{abstract}

Keywords: diffusion, participatory democracy, public policy, participatory budget, Brazil. 


\section{Adoção de políticas inovadoras: o Orçamento Participativo brasileiro}

Políticas inovativas se difundem por países, por regiões e pelo mundo sob a batuta de organizações não governamentais (ONGs), instituições internacionais de financiamento, partidos políticos, ativistas da sociedade civil e políticos empreendedores. A ampliação do número de regimes democráticos ao longo dos últimos trinta anos foi acompanhada pela adoção de instituições de formulação de políticas que oferecem aos cidadãos acesso direto às instâncias decisórias. Ainda que um esforço considerável tenha sido feito para promover a adoção de políticas de boas práticas que dessem voz direta aos cidadãos na formulação de políticas, seguimos carecendo de uma análise sistemática que explique por que e sob que condições os governos de países recentemente democratizados e em desenvolvimento se revelam dispostos a adotá-las. O que explica a difusão de boas práticas em novas democracias? Seria a expansão das redes de políticas públicas, apoiadas por ONGs nacionais e internacionais, o que promove a adoção de novas políticas? Ou seriam as estratégias políticas de políticos individuais e partidos, à medida que procuram promover políticas inovadoras na busca de apelo junto aos eleitores? A primeira seção deste artigo procura abordar esses temas.

Os governos tendem com freqüência a adotar políticas de boas práticas com base nos pretensos sucessos de casos modelares, mas ainda nos falta a compreensão básica sobre a possibilidade de que as políticas adotadas produzam resultados similares aos obtidos no conjunto inicial de casos. No que diz respeito às políticas, em que medida a presença de empreendedores, defensores ou adotantes formais pode afetar a probabilidade de que um governo obtenha um resultado similar àquele pretendido pela política de boa prática? A segunda parte do artigo aborda essa questão. Apesar da promoção de boas práticas ter sido rotinizada, no mais das vezes por meio de redes de políticas públicas e pressões eleitorais, há insuficiente evidência para demonstrar se a promoção de programas inovadores geram os resultados almejados.

Empreendedores políticos despendem considerável tempo, energia e recursos para introduzir políticas; também trabalham para assegurar que estas produzam resultados positivos, pois suas carreiras políticas estão estreitamente vinculadas à sorte das novas políticas adotadas. Defensores de políticas públicas, por sua vez, garantem apenas níveis limitados de apoio à nova política, uma vez que agentes governamentais têm comparativamente menos ganhos políticos potenciais; eles não mobilizam apoio suficiente para que se produzam os resultados significativos normalmente associados aos casos iniciais de boa prática. Finalmente, adotantes formais de tais políticas dedicam apenas níveis mínimos do tempo, da energia e dos recursos que seriam necessários para fazer com que a 
política inovadora fosse bem-sucedida; esse conjunto abrange funcionários que se juntam à corrente ou que são levados a implementar a referida política por indução de seu partido político.

O programa brasileiro de Orçamento Participativo (OP) é uma instituição participativa de amplo alcance, cuja iniciativa coube a governos municipais e a ativistas da sociedade, movidos pela esperança de criar processos orçamentários públicos, abertos e transparentes, que permitissem aos cidadãos se envolverem diretamente na seleção de resultados específicos de políticas públicas (ABERS, 2000; BAIOCCHI, 2005; AVRITZER, 2002). A transição brasileira para a democracia ao longo da década de 1980 foi acompanhada pela descentralização de autoridade e recursos em favor de estados e municípios, o que garantiu às prefeituras a flexibilidade para experimentar novas modalidades institucionais (MONTERO e SAMUELS, 2004). Isso representou claramente uma "janela de oportunidade", na medida em que grupos que há muito eram mantidos à margem do poder político se viram capazes de vencer as eleições em alguns dos municípios mais importantes do país, como em São Paulo, Belo Horizonte, Recife e Porto Alegre (KINGDON, 1995; BAUMGARTNER e JONES, 1993).

O Orçamento Participativo foi inaugurado pelo governo do PT na prefeitura de Porto Alegre, em 1989, tendo sido a partir de então adotado por um grande número de municípios. Mais de 300 prefeituras brasileiras adotaram o programa entre 1989 e 2004, além de cidades em pelo menos outros 30 países (WAMPLER e AVRITZER, 2005; CABANNES,s.d.). No início, o OP esteve estreitamente associado aos governos municipais do PT. Os líderes do partido o promoveram fortemente, algo que se evidencia com maior eloqüência no fato de que $100 \%$ dos governos do PT em grandes municípios (definidos por uma população maior que 100.000 habitantes) tenham adotado o OP entre 1989 e 2004. Mas a história de sua adoção é muito mais complexa, como mostra o Gráfico 1. Por volta de 2001, praticamente dois terços das novas adoções do OP ocorriam em cidades que não eram administradas pelo PT. Qual razão explica por que rivais políticos adotaram um programa tão claramente associado ao PT? 


\section{Gráfico 1. Adoção do Orçamento Participativo, 1989-2004 Municípios com mais de $\mathbf{1 0 0 . 0 0 0}$ habitantes}

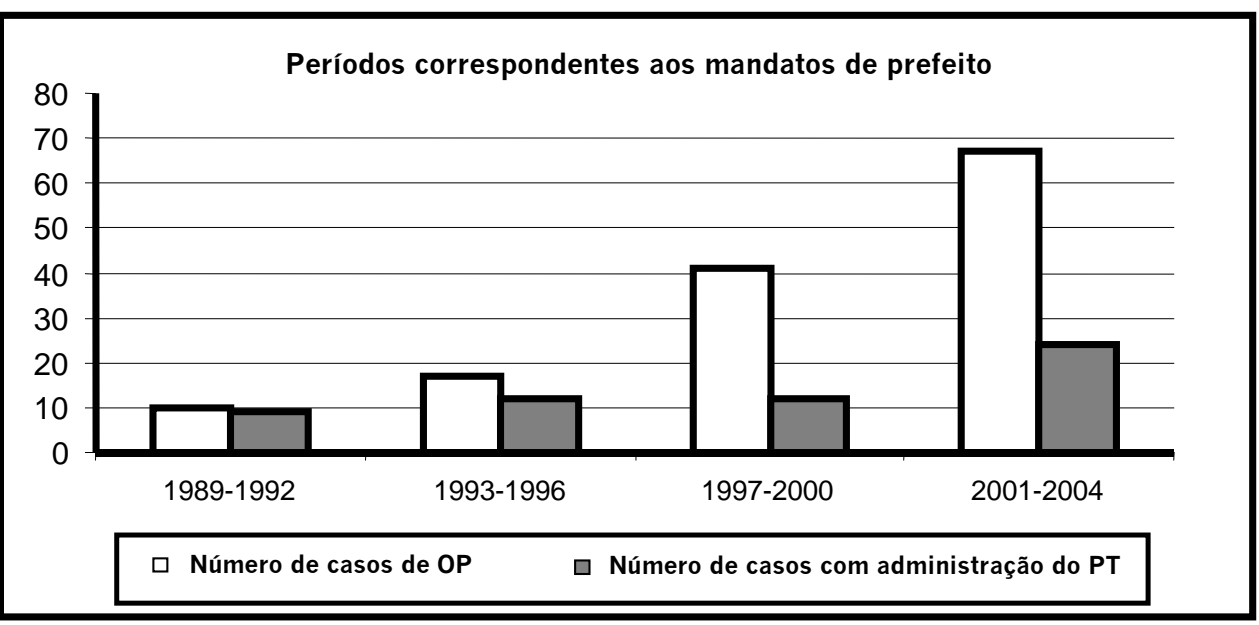

Este artigo começa com uma breve introdução aos componentes básicos do OP, destacando seu papel como uma instituição inovadora na formulação de políticas. Em seguida, há um breve sumário dos debates em torno da idéia de difusão. A primeira seção empírica explica a adoção do OP por municípios brasileiros entre os anos de 1989 e 1996. A segunda seção empírica desenvolve um modelo testado com regressão logística, de modo a revelar quais fatores mais fortemente afetaram a probabilidade de que um governo municipal adotasse o OP durante os mandatos de 1997 a 2000 e de 2001 a 2004. A seção final do artigo introduz duas novas categorias, defensores de políticas (policy advocates) e adotantes formais (pro forma adopters), que procuram expandir o debate sobre empreendedores na esfera das políticas públicas. Os dados incluídos nessa seção final foram extraídos de um estudo realizado entre 2003 e 2004 em oito municípios brasileiros e procuram demonstrar que a adoção de políticas inovadoras de modo algum é uma garantia de que resultados similares se produzam em contextos distintos. Os dados apresentados são preliminares, mas sugerem que a ampliada promoção de „boas práticas“ não é necessariamente algo positivo.

\section{O que é o Orçamento Participativo?}

O sistema federativo brasileiro assegura aos municípios a transferência de cerca de $15 \%$ de todos os gastos públicos, o que ajuda a explicar por que 
movimentos sociais, ONGs, associações comunitárias e políticos dedicam tanta atenção aos orçamentos municipais (MONTERO, 2000; MONTERO e SAMUELS, 2004; WAMPLER, 2007). Os prefeitos brasileiros dispõem de considerável autonomia, o que permite que desenvolvam novos programas com um grau mínimo de interferência por parte das instâncias legislativas municipais, as câmaras de vereadores (WAMPLER, 2007).

O Orçamento Participativo é um processo decisório que se estende por todo o ano fiscal. Em assembléias organizadas com esse fim, os cidadãos se engajam, juntamente com funcionários da administração, em negociações sobre a alocação de gastos que envolvam novos investimentos de capital em projetos tais como clínicas de assistência médica, escolas e pavimentação de vias públicas (ABERS, 2000; BAIOCCHI, 2005; NYLEN, 2003; WAMPLER e AVRITZER, 2004)․․ É um programa inovador, pois suas regras promovem justiça social ao assegurar mais recursos para áreas mais pobres, ao encorajar a participação através da distribuição de recursos para cada uma das regiões do município em função da mobilização dos membros das respectivas comunidades e ao estabelecer novos mecanismos de responsabilização que acabam desvendando e inviabilizando procedimentos orçamentários obscuros. Nos casos em que o programa foi aplicado com mais sucesso, os cidadãos têm autoridade para tomar importantes decisões em relação às políticas públicas, o que realça seu potencial para transformar o processo decisório de base na política brasileira (ABERS, 2000; WAMPLER, 2007). Os programas de OP combinam elementos de democracia direta (p. ex., a mobilização direta de cidadãos em assembléias decisórias) e de democracia representativa (p. ex., a eleição de delegados).

O OP foi inicialmente parte de um projeto mais amplo de transformação política que a liderança do PT acreditava seria capaz de criar novos tipos de cidadãos e de transformar as relações entre Estado e sociedade, por meio da delegação de autoridade aos cidadãos (GENRO, 1995; AVRITZER, 2002). Avaliar a inteira medida do impacto que o OP teve sobre os governos, cidadãos e relações entre Estado e sociedade é algo que extrapola o objetivo deste artigo, mas a maioria das análises acadêmicas sugere que o caso pioneiro de Porto Alegre contribuiu para fomentar a deliberação, a justiça social e o capital social (ABERS, 2000; AVRITZER, 2002; BAIOCCHI, 2005). Pesquisas comparativas confirmaram que os notáveis sucessos de Porto Alegre não foram necessariamente confirmados em outras experiências (NYLEN, 2003; WAMPLER e AVRITZER, 2004; WAMPLER, 2007). Ainda que as mudanças mais ambiciosas esperadas e defendidas pelo PT e por seus aliados na sociedade civil não tenham se materializado, o OP foi reconhecido como um instrumento que levou as prefeituras a reestruturar seus processos tradicionais

\footnotetext{
${ }^{1}$ Para uma descrição mais detalhada das regras, ver: < http://www.internationalbudget.org/resources/libray/GPB.pdf.> Acesso em: 25 out.2006.
} 
de formulação de políticas públicas e tornou-se parte de um pacote de reformas vinculado às práticas de "boa governança" (HUNTER, 2004; GUIDRY, 2003; WAMPLER e AVRITZER, 2005), recebendo atenção internacional quando as Nações Unidas o incluíram em uma lista das 40 melhores práticas na Conferência do Hábitat (Programa das Nações Unidas para os Assentamentos Humanos), em 1996, em Istambul.

\section{O debate sobre a difusão}

Difusão é a adoção pelos governos de programas similares, de uma forma não coordenada, mas interconectada (ELKINS, 2003). "A difusão de políticas públicas pode ser descrita por uma curva logística ascendente ou por uma curva em forma de S. A adoção da política é lenta no início, muito rápida em seguida, voltando a ser lenta à medida que o ponto de saturação é alcançado“ (BAUMGARTNER e JONES, 1993, p.17). Apesar de existir atualmente uma ampla e desenvolvida literatura sobre a difusão de instituições entre os estados norteamericanos ou entre os estados nacionais, sabemos muito pouco sobre os processos que podem levar à difusão entre unidades subnacionais nas novas democracias da América Latina, da Europa do Leste, da Ásia e da África (BERRY, 1994; WALKER, 1969; BERRY e BERRY, 1990; COLLIER e MESSICK, 1975; HISKEY e CANACHE, 2005).

Nos debates sobre a difusão subnacional no contexto norte-americano, os acadêmicos recorrem a dois tipos básicos de argumentos para explicar a adoção de políticas públicas. Primeiro, determinantes internos, tais como renda, resultados eleitorais e gastos governamentais, fatores que são postulados como influentes na adoção de um dado programa, na medida em que municípios com características similares tendem a adotar políticas similares (WALKER, 1969; MINTROM, 1997). Políticos tendem a adotar políticas que apelem a suas bases de apoio ou a um bloco de eleitores que possa influir no equilíbrio eleitoral. No Brasil, municípios mais ricos, por exemplo, têm uma camada mais extensa de classe média e revelamse mais propensos a apoiar esforços de "boa governança", por conta da ênfase sobre a transparência, o acesso e a abertura, delineados como instrumentos de contenção da corrupção reinante. Empreendedores políticos são mais propensos a eleger-se em municípios que contam com um número maior de ativistas interessados na mudança, além de uma faixa mais ampla de classe média interessada na "boa governança".

Em segundo lugar, redes de políticas públicas também ajudam a explicar a probabilidade de que governos procurem por boas idéias mais além das fronteiras de sua jurisdição (BERRY e BERRY, 1990). Políticos e organizações da sociedade 
civil recorrem a redes de políticas públicas na tentativa de obter informações a respeito de inovações em curso fora de seu domínio local (WEYLAND, 2004). A difusão de uma política através de redes de políticas públicas tende mais a gerar defensores de políticas e adotantes formais do que empreendedores políticos, por duas razões: em primeiro lugar, uma dada política provavelmente não gerará para os funcionários do governo que a adota os mesmos benefícios políticos - seja no âmbito estadual, nacional ou internacional - que teria gerado para os empreendedores de políticas públicas, porque os políticos e os partidos estão, afinal, meramente copiando políticas bem-sucedidas, o que significa que seu ganho político respectivo dificilmente poderá ser equivalente ao obtido nas experiências nas quais se espelham; em segundo lugar, o contexto político e social no qual a política está sendo implementada pode ser tão diferente da experiência inicial que o governo pode acabar se vendo diante de uma recepção refratária da parte de suas bases de apoio e dos cidadãos em geral. Os cidadãos que se convertem em participantes ativos nos programas de OP podem perceber que têm pouco a ganhar com um tal programa, o que inevitavelmente produz uma atitude ambivalente em relação à nova política.

Uma terceira explicação para a adoção da política, que vincula as duas explicações anteriores, refere-se à promoção ativa de uma política específica por um partido político, uma organização internacional ou uma ONG. Em lugar da expansão não coordenada de uma política, existe neste caso um ator específico que abertamente a promove. No caso dos partidos políticos, a liderança pode advogar a adoção de uma política em particular ou de um realinhamento institucional, de modo a aumentar as chances eleitorais do partido ou a caracterizá-lo como uma agremiação reformista. Lideranças partidárias trabalham em conjunto com redes de políticas públicas para promover junto a forças aliadas políticas que possam ampliar seu apelo. Ora, o Brasil tem um sistema pluripartidário no qual pelo menos cinco partidos têm chances de ganhar eleições num número significativo de municípios de maior porte e maior grau de urbanização. Assim, as redes de políticas públicas no país não são controladas por um único partido, sendo mais claramente influenciadas por dois grandes partidos (PT e PSDB), que se caracterizam por perseguir mais agressivamente suas metas reformistas. 


\section{Explicando a adoção}

O que explica a difusão de inovações em termos de políticas públicas nos grandes municípios brasileiros?

\section{Eleições}

A eleição direta de prefeitos nas capitais estaduais e nos grandes municípios foi reinstituída no Brasil em 1985, após um hiato de 21 anos, devido à ditadura militar. Evidentemente, as eleições ofereceram incentivos para que prefeitos adotassem políticas com apelo junto aos cidadãos, de modo a poder assegurar os votos de importantes eleitorados. Durante as décadas de 1980 e 1990, as eleições municipais representaram fontes de considerável incentivo para que prefeitos e candidatos a prefeito posassem como reformistas, também devido à percepção de que os governos militares haviam abusado de sua autoridade ao promover a centralização do poder estatal, permitir a proliferação da corrupção e isolar o Estado diante das demandas dos cidadãos. Mais que qualquer outro partido, o PT procurou apresentar-se como um partido que introduziria projetos transformadores, capazes de transferir o poder diretamente para as mãos dos cidadãos. Era de se esperar que sobretudo os prefeitos do PT adotassem o OP, porque isso os associaria aos olhos dos eleitores à bem-sucedida experiência de Porto Alegre.

As eleições para as câmaras de vereadores representaram outro mecanismo que ajudou a promover novas formas de responsabilização. Legisladores de esquerda são mais propensos que aqueles de direita ou de centro a apoiar a adoção de programas de OP nos municípios governados pelo PT, pois as forças à esquerda do espectro político se utilizam-se de mecanismos de mobilização de base e de instituições participativas como meios para construir sua plataforma de apoio. As idéias centrais do OP coincidem com o quadro básico de idéias associadas à esquerda no espectro político brasileiro. Contudo, quando o prefeito não é do PT, como é que a presença de vereadores de esquerda afeta a probabilidade de que o OP seja adotado? Seria razoável afirmar que um aumento no número de vereadores de esquerda favorece que prefeituras de outros partidos adotem o OP, na tentativa de evitar que ele se torne um trunfo eleitoral do PT e de seus aliados à esquerda. Conforme aumenta o apoio eleitoral para candidatos de esquerda, prefeitos de outros partidos tendem a aproximar-se do eleitor médio e adotar um programa de políticas públicas mais próximo do perfil do PT. Por outro lado, também é plausível que, à medida que aumenta o apoio para vereadores de esquerda, haja menos propensão para que governos de outros partidos adotem o OP, porque tais governos não gostariam de se associar a um tema que é "da alçada" do PT. 
$\underline{\text { Redes de políticas públicas }}$

O PT, seus aliados na sociedade civil e outras ONGs dedicadas à reforma dos mecanismos de governança, à participação direta dos cidadãos e ao combate à pobreza foram os principais agentes de promoção do OP ao longo dos anos 1990. Quando governos se envolvem em redes de políticas públicas, é mais provável que estejam dispostos a adotar um programa inovador do que governos que se mantêm isolados em relação a essas redes. Prefeitos procuram coletar informações sobre aquilo que os possa ajudar a governar com maior eficácia, assim como sobre aquilo que os possa favorecer em eleições futuras. A atenção de acadêmicos e formuladores de políticas públicas se concentrou fundamentalmente sobre os casos de Porto Alegre e, em menor medida, de Belo Horizonte, duas capitais estaduais nas quais o partido governante foi capaz de eleger sucessivos prefeitos, ao mesmo tempo em que se implementavam programas de OP bem-sucedidos. Assim, o programa revelou-se uma atraente alternativa para prefeitos envolvidos em redes de políticas públicas orientadas pela idéia de "boa governança", pois oferecia uma oportunidade de assegurar melhores resultados às políticas adotadas, enquanto simultaneamente ajudava os candidatos em suas tentativas de reeleição.

\section{Determinantes internos}

Como foi suficientemente documentado nos debates sobre a democratização, incrementos de renda são claramente associados a demandas da parte dos cidadãos por um papel maior na seleção de líderes e nas decisões sobre como serão distribuídos os recursos públicos. O OP é uma instituição que tem o potencial de aprofundar a democracia por meio do destaque dado à voz e ao voto dos cidadãos em debates públicos sobre o rumo das políticas públicas, o que sugere haver uma conexão entre renda crescente e demandas por maior participação dos cidadãos nos assuntos de Estado. Os programas de OP foram inicialmente implantados em municípios comparativamente mais ricos, com níveis mais altos de qualidade de vida. A razão fundamental por trás disso se encontra no fato de que a base de apoio do PT estava em cidades com um grande contingente de trabalhadores sindicalizados e amplas faixas de classe média, dois dos grupos sociais que mais apoiaram o PT em seus esforços para redefinir os processos de formulação de políticas públicas no Brasil.

O OP permite que os cidadãos decidam diretamente sobre a alocação de porções dos novos fundos de investimento de capital do orçamento municipal, sendo assim plausível que baixos níveis de novos investimentos de capital por parte dos governos encarregados de geri-los possam levar os cidadãos a votar em favor de um partido político que se dedique a depurar o governo por meio de políticas e 
programas como o OP. Assim, à medida que os investimentos per capita diminuem, há uma crescente probabilidade de que eleitores e políticos da oposição favoreçam uma política inovadora, expressamente destinada a elevar o montante dos recursos que podem ser gastos com novos fundos de investimento de capital do município.

\section{Determinantes regionais}

O Brasil é dividido em cinco grandes regiões administrativas. O sul e o sudeste têm grandes centros industriais e uma produção agrícola diversificada, enquanto o nordeste é dominado pela monocultura, possui uma indústria incipiente e altos índices de pobreza. O centro-oeste é uma área de rápida expansão agrícola, com um número reduzido de municípios de grande extensão territorial, enquanto o norte é dominado pela bacia do rio Amazonas, contando com algumas poucas cidades de médio ou grande porte. O OP foi implementado inicialmente na cidade de Porto Alegre, onde se tornou associado estreitamente ao PT. O padrão de adoção no sul é diferente do resto do país, provavelmente porque os governos de outros partidos nessa região são menos propensos a adotar o OP, em decorrência de sua estreita vinculação com o partido e com a experiência da capital gaúcha: os governos do sul se revelaram refratários à adoção de programas participativos, que na região carregavam em última instância o "selo" do PT. Nas outras regiões do país, prefeituras governadas por outros partidos demonstravam uma maior propensão a adotar O OP, porque os prefeitos tinham mais chances de extrair benefícios políticos pessoais do que teria um prefeito de outro partido que não o PT na região sul.

\section{Seleção de casos}

Programas de OP foram implementados em cidades com populações que variavam de 4.000 a 10 milhões de habitantes. Comparar programas de OP em meio ao universo de todos os 5.500 municípios brasileiros representaria não somente um esforço quixotesco de coleta de dados, como dificilmente sustentaria qualquer explicação conseqüente, por conta das amplas diferenças regionais, econômicas, políticas e sociais entre todos esses municípios. Por exemplo, o Índice de Desenvolvimento Humano (IDH) médio do conjunto dos municípios brasileiros é de .699, sendo porém de .783 para municípios com mais de 100.000 habitantes e de .696 para municípios com menos de 100.000 habitantes.

Para que se pudesse estabelecer uma base metodológica mais sólida para este estudo e para que suficientes ganhos teóricos pudessem ser obtidos, apenas municípios com mais de 100.000 habitantes (de acordo com o Censo de 2000) 
foram considerados. Dos 225 municípios com mais de 100.000 habitantes, 27 adotaram o OP entre 1989 e 1996, enquanto outros 90 o adotaram em algum momento entre 1997 e 2004. Um total de 108 municípios, pouco menos da metade, jamais adotaram o OP. Em 2004, havia 103 casos de OP em municípios com mais de 100.000 habitantes, significando que $25 \%$ da população brasileira vivia então num município que utilizava o OP como parte de seu processo de formulação de políticas públicas.

\section{Explicando a adoção durante a primeira onda: 1989-1996}

A origem do OP é comumente reconhecido como sendo a capital gaúcha, Porto Alegre, cuja prefeitura fora conquistada pelo PT em 1988. O governo petista trabalhava estreitamente com organizações da sociedade civil local (OSCs) para desenvolver o conjunto básico de regras que criaria a instituição participativa que viria a ser conhecida como OP (ABERS, 2000; AVRITZER, 2002; FEDOZZI, 1998). A liderança do PT em Porto Alegre revelou muitas das características típicas dos empreendedores políticos - agentes políticos marginais que utilizam sua surpreendente vitória eleitoral como ensejo para experimentar novas políticas e para construir uma sólida base de apoio (ABERS 2000; FEDOZZI 1998).

As vitórias eleitorais do PT em 1988 e 1992 ocorreram em grandes municípios, comparativamente mais ricos e com IDH mais alto. Níveis mais altos de qualidade de vida refletem a presença de amplas camadas de classe média e de sindicatos organizados, o que ajudava a sustentar o partido em seu esforço por estabelecer um "modo petista de governar", que fosse capaz de transformar a política e a sociedade brasileiras. Ao longo do final da década de 1980 e início da década de 1990, o PT atraía predominantemente trabalhadores sindicalizados, ativistas de organizações da sociedade civil e os setores mais ideologizados da classe média (KECK, 1992; SAMUELS, 2004). Apesar de se posicionar como o partido que transformaria as vidas dos excluídos e desfavorecidos no país, a principal base de apoio do PT constituiu-se inicialmente dos setores sindicais e de classe média, que se encontravam em situação consideravelmente melhor que seus concidadãos.

No período entre 1989 e 1992, o PT governou 9 das 10 cidades que adotaram o OP, todas localizadas nas regiões industriais do país, no sul e no sudeste. O único governo de outro partido que adotou o programa (a prefeitura de Vila Velha) situava-se nas proximidades de uma capital estadual (Vitória - ES) governada pelo PT e com adoção do OP.

De 1993 a 1996, o PT administrou 12 dos 17 municípios que adotaram o OP (66\%). No intervalo mais amplo, entre 1989 e 1996, governou 21 dos 27 municípios que o adotaram (78\%). O partido se situava claramente no centro dos 
esforços para promover a adoção do programa. Todos os governos petistas em grandes municípios (com mais de 100.000 habitantes) acabaram adotando o OP entre 1989 e 2004. Funcionários do partido em Porto Alegre e São Paulo disseminavam informações sobre o programa, especialmente depois que a experiência de Porto Alegre passou a ser considerada um sucesso (VILLAS BOAS, 2004; ASSIS, 1998; SOLER, 1998; FEDOZZI, 1999).

No quadro do sistema pluripartidário brasileiro, o PT se destaca como um partido comparativamente bem estruturado e com alto grau de disciplina interna, que deu início a uma ampla gama de inovações em termos de políticas públicas, incluindo o Orçamento Participativo, o programa de subvenções escolares conhecido como Bolsa Escola e um programa de suplementação da renda familiar conhecido como Renda Mínima (HUNTER, 2004; GUIDRY, 2003; SUGIYAMA, 2006). Nesse período, as administrações petistas revelaram-se dispostas a experimentar novas configurações institucionais, que acabavam por colocar em xeque as relações tradicionais entre Estado e sociedade, por meio da reorganização das instituições políticas. Três fatores específicos explicam melhor por que o PT adotou o OP: um sólido embasamento na sociedade civil, coesão partidária interna e a presença de empreendedores políticos que buscavam criar políticas inovadoras, não somente diferenciadas das políticas propostas por seus adversários, mas que também enfatizavam claramente a participação dos cidadãos, a justiça social e a transparência (WAMPLER e AVRITZER, 2005).

A expansão descoordenada do OP já estava em curso no período entre 1993 e 1996. Sua adoção nessas 5 cidades administradas por outros partidos pode ser explicada pela ampliação das redes de políticas públicas. Duas ONGs em especial . FASE(Federação de Órgãos para Assistência Social e Educacional) e o Instituto Pólis - começaram a fornecer a governos de outros partidos informações sobre as regras do OP (VILLAS BOAS e TELLES, 1995; VILLAS BOAS, 2004; GRAZIA, 2003). Dois dos seis casos referentes a administrações de outros partidos tiveram lugar em capitais estaduais (Recife - PE e Salvador - BA), ambas contando com sedes locais da FASE, diretamente envolvidas na disseminação de informações (FEDOZZI, 1999; GRAZIA, 2003; SOLER, 1998). Em Recife, por exemplo, Salvador Soler estava encarregado da implementação do OP e havia obtido de colegas da FASE informações sobre o programa. Viajando em seguida a Porto Alegre, pôde ter pessoalmente contato com seu modo de funcionamento (SOLER, 1998). Dois dos outros cinco casos de OP tiveram lugar em cidades de médio porte, geralmente próximas a uma capital estadual que já havia dado início ao programa.

A adoção ao programa tem uma importante dimensão regional. Quatro dos cinco municípios administrados por outros partidos que adotaram o OP encontravam-se fora da região sul, onde o OP estava mais claramente associado à imagem do PT e da experiência pioneira de Porto Alegre. Governos reformistas no 
sul pareciam pouco dispostos a adotar uma iniciativa política estreitamente vinculada a seus adversários políticos petistas. O único caso de uma administração de outro partido no sul aconteceu em Lages, uma cidade de médio porte no estado de Santa Catarina. É a exceção que confirma a regra, pois ali as administrações municipais já haviam desenvolvido programas participativos ainda durante o regime militar (PIRES, 2002). Os políticos locais podiam adotar formalmente o OP sem temor de estarem cedendo terreno político ao PT, uma vez que as raízes dos experimentos participativos poderiam ser remetidas a um período anterior à consolidação do PT no município.

Em resumo, a adoção inicial do OP esteve fortemente associada ao PT, mas o quadro se tornou mais complexo em decorrência do fato de que dois terços das prefeituras que adotaram o programa durante os períodos respectivos de 1997 a 2000 (68\%) e de 2001 a 2004 (64\%) eram administradas por outros partidos (ver Gráfico 1). O que explica que outros partidos adotassem o OP? O que pode explicar a disseminação do OP para além das cidades governadas pelo PT?

Segunda onda de adoção: 1997-2004

O número de municípios que adotaram novos programas de OP aumentou de 41, em 1997, para 67, em $2004^{2}$. As características políticas e sociais dos municípios que adotaram o programa mudou consideravelmente em relação ao período inicial, entre 1989 e 1996, demandando uma correspondente adaptação em termos metodológicos. Entre os 41 novos casos em 1997, apenas 13 envolviam adoções pelo PT, sendo 28 os casos de adoção por outros partidos. Para explicar isso, foi desenvolvido um modelo que incluiu determinantes eleitorais, redes de políticas públicas e variáveis regionais.

Um modelo de regressão logística foi utilizado para testar quatro variáveis dependentes. Variáveis dicotômicas (dummy) foram estipuladas para os períodos referentes aos mandatos municipais - 1997 a 2000 e 2001 a 2004 - em função da adoção do OP pelo respectivo município ( $\operatorname{sim}$ ou não). Todos os municípios que tinham OP durante intervalos anteriores foram excluídos (p. ex., para o período entre 1997 e 2000, todas as prefeituras que já haviam adotado o OP entre 1993 e 1996 foram excluídas). Há dois testes para cada período: o primeiro envolve todos os municípios, enquanto o segundo exclui todas as prefeituras do PT para explicar

\footnotetext{
2 Para identificar quais municípios praticavam o OP durante o período entre 1997 e 2000, apoiamo-nos no volume organizado por Ana Clara Torres Ribeiro e Grazia de Grazia, que trabalharam com o Fórum Nacional de Participação Popular. Para o período entre 2001 e 2004, recorremos, juntamente com dois assistentes de pesquisa, ao contato direto com as prefeituras de municípios com mais de 100.000 habitantes. Combinamos as informações obtidas com os resultados de uma equipe de pesquisa coordenada por Leonardo Avritzer, da Universidade Federal de Minas Gerais (UFMG). Ao longo de nossas investigações relacionadas ao período de 2001 a 2004, descobrimos que os programas de OP iniciados antes de 2001 não haviam sido incluídos no estudo de Torres e Grazia.
} 
melhor por que administrações de outros partidos adotam um programa de políticas públicas de início fortemente identificado com o PT.

Em primeiro lugar, uma variável dicotômica, Prefeito do PT, foi estipulada, tanto para as eleições de 1996 quanto para as de 2000, conforme o prefeito eleito fosse do PT ou de outro partido. Se essa variável tem sinal positivo e é estatisticamente relevante, ela indica se a adoção do OP continuava fortemente associada à administração municipal do PT. Uma segunda variável eleitoral diz respeito ao percentual de cadeiras obtidas por forças políticas de esquerda na respectiva Câmara de Vereadores. Se essa variável tem sinal positivo e é estatisticamente significante, ela indica se o OP continuava sendo adotado em municípios onde a esquerda tinha uma sólida base de apoio em comparação com outros municípios.

A terceira variável incluiu o Índice de Desenvolvimento Humano (IDH) para medir a o nível médio de qualidade de vida numa dada localidade. O IDH congrega a renda per capita, o nível de alfabetização da população adulta e a expectativa de vida. No Brasil, esse índice é calculado com um referencial municipal e pontuações mais altas indicam um nível correspondentemente mais alto de qualidade de vida ${ }^{3}$. Se essa variável tem sinal positivo e é estatisticamente significante, ela indicará se o OP continuava sendo adotado em municípios comparativamente mais ricos.

A quarta variável se refere aos gastos orçamentários per capita em termos de novos fundos de investimento de capital, pois é esse o tipo de gasto público em torno do qual se concentra a maioria dos programas de OP. Utilizamos os gastos per capita com novos investimentos de capital no ano eleitoral anterior ao início do mandato de prefeito da administração que adotou o programa (respectivamente, 1996 e 2000). Se essa variável tem sinal negativo e é estatisticamente significante, ela indicará se o OP era adotado em circunstâncias nas quais a administração que deixava a prefeitura havia dedicado menos recursos a novos investimentos de capital do que havia sido o caso em outros municípios de dimensões comparáveis.

Uma quinta variável procura medir o grau de envolvimento de um dado município com redes de políticas públicas voltadas à "boa governança", uma variável dicotômica estipulada com base na inclusão do respectivo município no projeto "Inovações na Gestão Pública" [sn1], patrocinado pela Fundação Getúlio Vargas e pela Fundação Ford ${ }^{4}$. Esse programa, iniciado em 1996 com base no modelo da Universidade de Harvard, o "Innovation Project", oferece premiações em dinheiro e considerável reconhecimento e prestígio para 10 projetos de gestão municipal selecionados por um comitê de avaliação. As prefeituras inscrevem seus próprios programas na competição, indicando que funcionários da gestão pública

\footnotetext{
${ }^{3}$ Ver $<$ www.undp.org.br $>$.

${ }^{4}$ Ver < http://inovando.fgvsp.br >.
} 
buscam reconhecimento para aquilo que consideram ser seus programas "inovadores". Se essa variável tem sinal positivo e é estatisticamente significante, ela indicará se o OP era adotado por administrações cujos prefeitos se apóiam em referenciais situados para além de suas localidades na busca de soluções para problemas agudos de gestão pública.

A última é uma variável que distingue a região sul do resto do país. Uma análise descritiva sugere que um processo diferenciado de adoção ocorre no sul, em contraste com as outras regiões. Ali, entre 1997 e 2004, cerca de 90\% dos municípios que adotaram o OP eram governados pelo PT (88\%). No resto do Brasil, no mesmo período, pouco mais de um terço das prefeituras que o adotaram (35\%) eram do PT, indicando portanto uma dinâmica substancialmente distinta em ação no sul.

Essas seis variáveis cobrem um amplo espectro de explicações possíveis, envolvendo desde determinantes internos da difusão até elementos de política partidária. Esse modelo deve nos ajudar a explicar melhor por que metade dos grandes municípios brasileiros já havia adotado o OP por volta de 2004.

\section{7-2000: 41 novos casos de OP}

Das seis variáveis incluídas no modelo, quatro são estatisticamente significantes e ajudam a calcular a probabilidade de que uma prefeitura adote o OP (ver Tabela 1). Talvez o mais surpreendente seja o fato de que o próprio PT não tenha implicado qualquer significância estatística. Dado que $78 \%$ dos municípios que adotaram o OP no período entre 1989 e 1996 eram governados pelo PT, o quê mudou? O ano de 1996 foi, no fim das contas, um ano eleitoral muito desfavorável para o partido, que conseguiu eleger apenas 12 novos prefeitos em grandes municípios. Se a presença de um prefeito petista não explica os resultados, o quê explica? 
Tabela 1. Adoção do Orçamento Participativo, 1997-2000 e 2001-2004

\begin{tabular}{|c|c|c|c|c|}
\hline & $\begin{array}{l}\text { 1997-2000 } \\
\text { Todos os casos }\end{array}$ & $\begin{array}{c}1997-2000 \\
\text { Excluídas as } \\
\text { administrações } \\
\text { do PT }\end{array}$ & $\begin{array}{l}\text { 2001-2004 } \\
\text { Todos os } \\
\text { casos }\end{array}$ & $\begin{array}{c}\text { 2001-2004 } \\
\text { Excluídas as } \\
\text { administraçõe } \\
\text { s do PT }\end{array}$ \\
\hline Prefeito do PT & $\begin{array}{l}11.59 \\
(5184)\end{array}$ & & $\begin{array}{l}1.78^{* * *} \\
(.408)\end{array}$ & \\
\hline$\%$ de vereadores de esquerda & $\begin{array}{l}5.21 * \\
(2.65)\end{array}$ & $\begin{array}{l}5.21^{*} \\
(2.65)\end{array}$ & $\begin{array}{l}-2.94 \# \\
(1.70)\end{array}$ & $\begin{array}{l}.311 \# \\
(1.79)\end{array}$ \\
\hline $\begin{array}{l}\text { Índice de Desenvolvimento } \\
\text { Humano }\end{array}$ & $\begin{array}{c}9.56 \\
(6.01)\end{array}$ & $\begin{array}{c}9.56 \\
(6.01)\end{array}$ & $\begin{array}{l}8.75 \# \\
(4.55)\end{array}$ & $\begin{array}{r}6.98 \\
(4.52)\end{array}$ \\
\hline $\begin{array}{l}\text { Rede de políticas públicas } \\
\text { baseada na "Boa Governança" }\end{array}$ & $\begin{array}{l}.580 * \\
(.280)\end{array}$ & $\begin{array}{l}.580 * \\
(.280)\end{array}$ & $\begin{array}{l}.242 \\
(.205)\end{array}$ & $\begin{array}{l}.167 \\
(.210)\end{array}$ \\
\hline Gastos com investimento & $\begin{array}{l}-.011 \# \\
(.006)\end{array}$ & $\begin{array}{l}-.011 \# \\
(.006)\end{array}$ & $\begin{array}{l}. .015^{*} \\
(.006)\end{array}$ & $\begin{array}{l}. .014^{*} \\
(.006)\end{array}$ \\
\hline Sul & $\begin{array}{l}-.956 \# \\
(.535)\end{array}$ & $\begin{array}{l}-.956 \# \\
(.535)\end{array}$ & $\begin{array}{l}.220 \\
(.265)\end{array}$ & $\begin{array}{l}. .112 \\
(.270)\end{array}$ \\
\hline $\begin{array}{l}\text { Constante } \\
\text { (log-likelihood) }\end{array}$ & $\begin{array}{l}.931 \\
(5184) \\
.112 .8\end{array}$ & $\begin{array}{l}-10.66^{*} \\
(4.752) \\
-112.8\end{array}$ & $\begin{array}{l}-4.97 \\
(3.49) \\
-174.9\end{array}$ & $\begin{array}{l}-5.28 \\
(3.47) \\
-162.5\end{array}$ \\
\hline $\begin{array}{l}N \\
\# \leq .1 ; * \leq .05 ; * * * \leq . .01 \\
* * * * \leq . .001\end{array}$ & 200 & 187 & 173 & 148 \\
\hline
\end{tabular}

Nas estimativas OLS aplicadas aos mesmos modelos, as tolerâncias para cada preditor são maiores que .10, indicando a ausência de multicolinearidade.

Erros-padrão entre parênteses.

Um primeiro fator explicativo diz respeito ao fato de que, apesar de ter sido tímido o desempenho do PT nos pleitos para prefeito, o partido e seus aliados de esquerda obtiveram ganhos consideráveis na disputa por cadeiras nas Câmaras de Vereadores ${ }^{5}$. Os resultados demonstram que, em municípios com percentuais mais altos de cadeiras obtidas por agremiações de esquerda, havia uma probabilidade mais alta de adoção de políticas inovadoras. Isso reforça a hipótese de que outros partidos, além do $\mathrm{PT}$, estavam dispostos a adotar tais políticas em resposta às demandas dos cidadãos relacionadas aos fundamentos estruturais do OP (transparência, justiça social e participação). É também provável que prefeitos de outros partidos tenham adotado o OP na tentativa de neutralizar uma questão que parecia ser "da alçada" do PT. O OP estava fortemente associado à imagem da esquerda brasileira em meados da década de 1990, fazendo com que prefeitos de

\footnotetext{
${ }^{5}$ Foram considerados partidos de esquerda o Partido dos Trabalhadores (PT), o Partido Comunista do Brasil (PC do B), o Partido Socialista Brasileiro (PSB) e o Partido Verde (PV).
} 
outros partidos o adotassem como forma de ganhar acesso a bases eleitorais interessadas nas reformas políticas introduzidas pelo PT. Isso indica que as eleições serviam também como mecanismos de "accountability", uma vez que os prefeitos tendiam a adotar o OP em resposta aos crescentes sucessos eleitorais da esquerda.

Em segundo lugar, a vinculação de uma prefeitura a uma rede de políticas públicas orientada pela "boa governança" também colabora para a adoção do OP durante o período entre 1997 e 2000. Os prefeitos aparentemente buscaram referenciais situados para além dos limites de seus próprios municípios e de cidades vizinhas, na intenção de obter informações relativas à reforma dos processos de formulação de políticas ${ }^{6}$. Esses prefeitos revelaram uma predisposição a orientar-se por outras experiências no esforço de aperfeiçoar sua gestão pública, de responder melhor às demandas dos cidadãos e de alcançar um melhor posicionamento de suas candidaturas à reeleição.

A adoção do OP se desenrolou no sul de uma forma diferente do que ocorreu no resto do país. Ali, como vimos, quase $90 \%$ dos municípios que adotaram o OP eram governados pelo PT. No sudeste e no nordeste, apenas $28 \%$ das prefeituras que o adotaram eram governadas pelo mesmo partido. Assim, no sul, a estreita associação entre o PT e o OP implicava que os outros partidos fossem refratários à sua adoção. No sudeste industrial e no nordeste pobre, os partidos políticos estavam mais dispostos a adotar o OP, pois suas bases eleitorais não necessariamente o associavam tão estreitamente ao PT. Não se trata de que governos de outros partidos estivessem cedendo terreno ao PT, mas, ao contrário, simplesmente tirando vantagem de um programa que se acreditava produziria resultados positivos em termos de gestão e de desempenho eleitoral.

Finalmente, na medida em que o nível per capita de gastos públicos com investimento no âmbito municipal decrescia, verificava-se uma probabilidade ligeiramente maior de que um governo recém-eleito adotasse o OP. Os resultados não são peremptórios, mas indicam que os novos governos empossados tinham uma maior propensão a adotar o OP quando o governo anterior havia dedicado montantes muito baixos de recursos aos gastos com novos investimentos de capital. Evidentemente, é bastante possível que governos que tivessem despendido montantes baixos de recursos per capita tivessem justamente perdido as eleições em razão da inabilidade em distribuir "parte do bolo" a grupos importantes. Porém, é significativo que administrações de desempenho mais tímido tivessem sido

\footnotetext{
6 Versões iniciais desse modelo incluíam medições de difusão estadual e regional. Os resultados não eram conclusivos, em parte devido às enormes diferenças no número de municípios em cada estado (60 municípios no estado de São Paulo e somente um no estado do Amazonas) e região (112 municípios no sudeste e somente 15 no norte).
} 
substituídas por outras mais propensas a adotar um programa inovador de políticas públicas, orientado por uma gestão transparente e depurada, que concedesse aos cidadãos autoridade decisória sobre recursos destinados a novos investimentos de capital.

Algo interessante e importante é o fato do IDH não se revelar estatisticamente significante. Durante o período de 1997 a 2000, uma marca média de .737 foi alcançada por municípios com OP, enquanto .716 era a marca média dos municípios sem OP. Comparativamente, durante o período de 1989 a 1993, havia uma marca média de .788 para os municípios com OP e .715 para aqueles que não tinham. Isso sugere um processo de "nivelamento", pois o OP havia extrapolado seu âmbito inicial de aplicação em cidades mais abastadas.

\section{Excluindo o PT: 29 novos casos}

Se excluirmos do modelo os municípios governados pelo PT, restam 29 casos para o período entre 1997 e 2000. Apenas 12 casos de administração petista foram excluídos, o que explica por que praticamente não existem diferenças entre as colunas 1 e 2 (Tabela 1). Novamente, é a participação de uma prefeitura numa rede nacional de políticas públicas e a crescente força eleitoral dos partidos de esquerda nas Câmaras de Vereadores o que mais ajuda a explicar a adoção do OP. A análise apresentada na seção anterior ainda serve, portanto, como a melhor explicação para a adoção do OP em todos os municípios.

\section{1-2004: 67 novos casos}

Para o período entre 2001 e 2004, a eleição de um prefeito petista no pleito de 2000 oferece a melhor explicação para a adoção do OP. Isso se distancia claramente do que se verifica para o período entre 1997 e 2000, quando a presença de um prefeito do PT não apresentava relevância estatística. A explicação óbvia é que, em municípios maiores e mais urbanizados, o PT havia obtido em 2000 sucessos eleitorais mais significativos do que em 1996, o que se traduz num maior número de casos de OP em grandes municípios. O OP foi adotado por todas as administrações do PT eleitas em municípios com mais de 100.000 habitantes.

É interessante notar que, na proporção em que decrescia a percentagem de vereadores de esquerda, aumentava a probabilidade de que o OP fosse adotado. Por que razão? Em primeiro lugar, os ganhos eleitorais do PT nas disputas por prefeituras não necessariamente encontraram correspondência direta nas cadeiras obtidas nas respectivas Câmaras de Vereadores. Isso indica que o PT, como partido, não estava ampliando suas redes locais e bases de apoio. Em lugar disso, o 
partido conseguiu atravessar uma antiga barreira eleitoral ao estimular os eleitores a apoiar seus candidatos a prefeito.

Uma segunda explicação se encontra no fato de que, em prefeituras administradas por outros partidos, há uma relação inversa entre a adoção do programa e o sucesso eleitoral de candidatos de esquerda. Os prefeitos parecem mais predispostos a adotar o OP em suas comunidades quando a esquerda ali é mais fraca. Esses prefeitos se dispõem a adotar um programa de gestão associado ao PT para (a) impedir que a esquerda local possa utilizar a inexistência do OP como bandeira de campanha e (b) obter acesso às bases sobre as quais o PT tradicionalmente se sustenta.

O IDH é estatisticamente significante para o período entre 2001 e 2004, o que significa que a adoção mais provável em municípios mais ricos. Em 2001, o PT foi eleito em municípios ricos, mas as administrações de outros partidos também se revelaram mais propensas a adotar o OP quando governavam municípios mais ricos. Isso sugere que os eleitores de classe média podem ter reagido à crença amplamente generalizada de que o OP ajudava a promover maior transparência na gestão pública. Apesar do fato de que a participação dos cidadãos no OP tende a ser dominada por indivíduos de classes mais baixas, os eleitores de classe média podem ter apoiado candidatos dispostos a se comprometer com uma nova forma de conduzir a política.

Finalmente, na medida em que, durante o ano eleitoral, diminuíram os gastos públicos municipais per capita com investimentos, verificou-se uma probabilidade proporcionalmente maior de que um governo recém-eleito adotasse o OP. Os resultados para o período entre 2001 e 2004 são ainda mais marcantes do que os do período anterior, sugerindo portanto que um governo recém-eleito que assumisse uma prefeitura com níveis muito mais reduzidos de gastos disponíveis com novos investimentos se revelaria mais propenso a adotar o OP como forma de depurar os mecanismos de gestão.

A participação de prefeituras no programa de premiação de iniciativas inovadoras já não é relevante estatisticamente, o que sugere que a informação sobre o OP já se disseminou amplamente o bastante para que uma administração não tivesse de estar envolvida numa rede específica de políticas públicas para que obtivesse informações sobre o programa. A rede de políticas públicas havia inundado o universo da formulação de políticas públicas com informações sobre o OP, até o ponto em que uma certa saturação foi alcançada. Por volta de 2001, o programa se havia convertido em parte de um pacote padronizado que administrações reformistas se dispunham a implementar. Isso indica que os governos que o adotam não necessariamente congregam empreendedores de políticas públicas, aproximando-se antes da figura de adotantes protocolares. Uma vez que os efeitos positivos associados ao OP incluem maior envolvimento das 
OSCs, um uso mais eficiente dos recursos públicos e um controle mais apurado sobre a burocracia, os governos se mostram dispostos a adotar tal política, porque têm o potencial de aumentar o prestígio pessoal dos administradores, especialmente por conta da prestação de serviços eficientes e transparentes.

\section{Excluindo o PT: 43 novos casos}

Quando os municípios administrados pelo PT são excluídos do modelo, os gastos com novos investimentos de capital e o percentual de vereadores de esquerda nas câmaras municipais são estatisticamente significantes. Uma redução no número de vereadores de esquerda leva a um aumento na probabilidade de que uma prefeitura adote o OP. Isso sugere que sua adoção é promovida por um esforço de políticos centristas e conservadores em identificar-se com uma política há tempos associada aos partidos de esquerda, num contexto, porém, em que podem postular a "paternidade" do programa. Políticos centristas e conservadores têm adotado o OP ali onde a concorrência representada pelas forças de esquerda é mais débil, buscando consolidar uma reputação de reformistas orientados pela "boa governança“.

Finalmente, na medida em que se reduz o montante de gastos per capita com investimentos, verifica-se um aumento na probabilidade de que uma prefeitura adote o OP. Novamente, governos recém-eleitos que assumem prefeituras nas quais o investimento per capita é baixo são mais propensos a adotar o OP como forma de apelar às bases eleitorais.

\section{Sintetizando os resultados relativos à adoção}

Durante os períodos de 1989 a 1996 e de 2001 a 2004, a presença do PT na prefeitura era o fator que mais bem explicava a probabilidade de que um município adotasse o OP. O partido se promoveu como uma agremiação de reformistas da "boa governança" e assegurou suficiente coesão interna a ponto de que o OP fosse adotado pela totalidade (100\%) das novas prefeituras conquistadas em grandes municípios. No período entre 1997 e 2000, não era a presença do PT o fator que explicava a adoção, mas a busca pelos governos de outros partidos de uma vinculação a redes de políticas públicas orientadas pela "boa governança" e uma alta porcentagem de vereadores de esquerda nas câmaras municipais. Prefeitos de outros partidos apoiaram-se em redes de políticas públicas para implementar políticas inovadoras ou extraídas de modelos de boas práticas que pudessem aperfeiçoar a gestão local e incrementar suas chances de reeleição. E ao longo do período que vai de 2001 a 2004, se os municípios administrados pelo PT são excluídos do modelo, dois fatores se destacam na explicação dos resultados: 
WAMPLER, B. A difusão do Orçamento Participativo brasileiro...

uma redução no número de assentos obtidos por candidatos a vereador de esquerda e um decréscimo no montante de recursos que o governo anterior havia despendido em novos investimentos de capital durante o último ano de sua administração. Isso sugere que administrações centristas e conservadoras são propensas a adotar o OP quando a esquerda é fraca e quando se constata a inépcia do governo anterior em investir na reforma das políticas públicas.

$\mathrm{O} O P$ se difundiu pelo Brasil, mas com que fim? Qual o impacto desses programas? Essas importantes questões empíricas se colocam com freqüência, pois os cidadãos, os cientistas sociais e os gestores públicos procuram saber se os impactos do OP são similares àqueles dos casos mais amplamente conhecidos (em especial, o de Porto Alegre). Extrapola, porém, o objetivo deste trabalho oferecer uma análise de todos os municípios que o adotaram. O restante deste artigo procura, assim, concentrar-se em oito casos específicos de OP, de modo a introduzir uma discussão a respeito do quanto à promoção das boas práticas acaba por produzir os efeitos almejados.

\section{Empreendedores da gestão pública, defensores de políticas e adotantes protocolares}

O Gráfico 1 mostra que até 2004 a adoção do OP no Brasil ainda se encontrava no ponto ascendente da trajetória da difusão ${ }^{7}$. Baumgartner e Jones afirmam que a difusão de políticas públicas é similar a um modelo de equilíbrio pontuado, no qual se verificam irrupções de ajuste de políticas, movidas pela abertura de vácuos de gestão que permitem aos empreendedores promover a adoção de novas políticas (BAUMGARTNER e JONES, 1993, p. 29). Kingdon descreve os empreendedores de políticas públicas como "dispostos a investir seus recursos - tempo, energia, reputação e dinheiro - para promover uma posição na expectativa de um retorno futuro sob a forma de benefícios materiais, práticos ou solidários“ (KINGDON, 1995, p. 179). Empreendedores de políticas públicas são com freqüência a força de arranque por trás da adoção de uma nova política, seja por razões políticas, pessoais ou gestionárias (MINTROM, 1997).

Além dos empreendedores de políticas públicas, dois outros tipos de liderança ajudam a explicar quais as modalidades de resultados das políticas que podem ser alcançadas. Defensores de políticas são aqueles funcionários do governo que implementam uma política com base em seu sucesso prospectivo, mas que

\footnotetext{
7 No período entre 2005 e 2008, havia apenas 110 municípios que não haviam adotado o OP, sendo portanto possível que a inclinação descendente da curva sigmóide terá início ao longo desse período, uma vez que a adoção do OP alcançou seu ponto de saturação.
} 
oferecem somente um apoio parcial a seus componentes centrais. Defensores podem introduzir uma política em um ambiente político hostil ou indiferente, um traço que compartilham com os empreendedores, sendo porém, ao contrário destes, pouco propensos a colocar em jogo suas carreiras políticas ou seu prestígio em favor do sucesso de uma política específica. Podem oferecer algum apoio político ao novo programa de gestão, mas seu nível de compromisso é consideravelmente mais baixo do que aquele demonstrado pelos empreendedores. É provável que os resultados gerados em termos de políticas públicas sejam substancialmente mais tímidos do que o que se poderia esperar a partir da consideração do quadro inicial de casos de boas práticas.

Adotantes formais são aqueles funcionários do governo que implementam uma política com base em seu sucesso prospectivo, mas que oferecem somente um apoio mínimo a seus componentes centrais. São convencidos por seus aliados políticos (freqüentemente por membros de seu próprio partido político) de que a adoção de uma política seria benéfica para sua administração, tanto em termos de gestão quanto em termos eleitorais. Eles também obtêm informações das redes de políticas públicas e podem optar por adotar uma política com base nelas. No entanto, são pouco propensos a dedicar o tempo, a energia ou os recursos necessários para fazer com que a política seja bem-sucedida. Esta é adicionada a uma agenda política e de gestão já existente, o que significa que os funcionários do governo possivelmente não mobilizarão seus melhores recursos humanos para a condução do programa ou deixarão de prover os fundos necessários para tanto.

Os prefeitos têm, portanto, diferentes incentivos para adotar políticas inovadoras. Aqueles que acreditam que obterão apoio e prestígio a partir da adoção do OP provavelmente dedicarão mais tempo, energia, recursos e, algo importante, prestígio político para assegurar que os programas em funcionamento em suas jurisdição sejam de algum modo semelhantes aos processos modelares vinculados à experiência pioneira de Porto Alegre. À medida que os rendimentos políticos para os prefeitos passam a mostrar sinais de recuo, haverá um correspondente recuo na intensidade do seu apoio.

Para verificar se existe uma associação entre o apoio oferecido pelo prefeito e os resultados da política, apoiamo-nos num estudo de oito municípios que adotaram o OP entre 1989 e 2004 (WAMPLER, 2007). Um amplo estudo de campo conduzido pelo autor sobre essa instituição participativa demonstra que dois indicadores básicos são excelentes instrumentos para monitorar o impacto do programa. O primeiro é a percentagem de gastos com novos investimentos de capital que o governo permite que os delegados do OP negociem. Isso revela o grau de risco político que os prefeitos estão dispostos a assumir ao considerar delegar autoridade. Os prefeitos brasileiros dispõem de considerável discricionariedade sobre assuntos orçamentários, de modo que um aumento no montante de recursos 
que os delegados do OP podem negociar é uma indicação de um maior apoio ao programa por parte do prefeito. Um segundo indicador é a percentagem dos delegados do OP pesquisados que declararam dispor "sempre" ou "quase sempre" da autoridade necessária para tomar decisões de gestão no quadro do programa, ilustrando o grau em que os participantes mais ativos (delegados eleitos do OP) acreditam que o programa permite que se envolvam diretamente na configuração dos resultados das políticas públicas ${ }^{8}$. As informações obtidas a partir desses questionários nos ajudam a avaliar se os participantes mais ativos acreditam que, como delegados eleitos, são capazes de exercer a autoridade que se esperava thes fosse reservada pela formulação dos programas de OP. Os questionários e a análise orçamentária são complementados com entrevistas com membros da elite, observações participantes, literatura secundária (acadêmica e oficial) e dados orçamentários, com o objetivo de classificar as lideranças governamentais como empreendedores, defensores ou adotantes formais.

O Gráfico 2 mostra que há uma forte vinculação por parte dos entrevistados entre suas atitudes em relação ao nível de autoridade de que gozam no OP e ao montante de recursos delegados à esfera decisória do programa, indicando que conceber os administradores como empreendedores, defensores ou adotantes formais oferece uma potente alavancagem analítica no esforço de compreender o impacto da difusão de políticas públicas. A presença de um empreendedor de políticas públicas na função de prefeito está fortemente relacionada com os índices de resposta positiva do survey. Empreendedores políticos colocaram em jogo seu futuro político no intuito de fazer prosperar essa nova modalidade institucional, que por sua vez ajudou a produzir resultados positivos em termos de políticas públicas. $\mathrm{Na}$ outra ponta do espectro, entrevistados atuando em municípios que contavam com prefeitos na posição de adotantes formais deram respostas mais brandas às questões relativas à autoridade, o que sugere que seus programas de OP não

\footnotetext{
8 O questionário foi elaborado e previamente testado em seu campo de aplicação, com a ajuda de Gustavo Venturi. A pesquisa foi realizada pelo Instituto Ethos, entre 25 de novembro e 10 de dezembro de 2003. Contemplou antes uma amostragem representativa de delegados do OP do que um apanhado aleatório, envolvendo um total de 695 questionários completos, em meio a um universo de 6.500 possíveis participantes. A distribuição entre os diversos municípios foi a seguinte: Porto Alegre (60), Ipatinga (60), Belo Horizonte (60), Santo André (60), São Paulo (300), Recife (60), Blumenau (60) e Rio Claro (30). Em todas as cidades, com exceção de Santo André, as entrevistas foram realizadas por via telefônica. Para produzir uma lista adequada com os telefones dos delegados atuais, o autor entrou em contato com cada uma das prefeituras para obter os respectivos nomes e telefones das pessoas que cumpriam o mandato de delegados do OP em 2003. Nos municípios de São Paulo, Ipatinga, Blumenau, Rio Claro e Recife, foram obtidas listas exaustivas de todos os delegados. A partir delas, os delegados a serem entrevistados foram selecionados aleatoriamente. Em Porto Alegre e Belo Horizonte, o gerenciamento municipal dos nomes e números de telefone havia sido descentralizado, sendo coordenado em nível inframunicipal. Em Porto Alegre, pudemos obter $50 \%$ dos números de telefone corretos, a partir dos quais realizamos uma seleção aleatória. Em Belo Horizonte, obtivemos menos de $30 \%$ dos nomes e números de telefone dos potenciais entrevistados, a partir dos quais realizamos a seleção aleatória. Em Santo André, as entrevistas foram realizadas pessoalmente, durante os encontros distritais do OP.
} 
funcionavam como se esperava inicialmente. As classes médias, lideradas por defensores de políticas, demonstraram um nível moderado de resultados positivos, com uma média de $47 \%$ dos entrevistados afirmando que dispunham "sempre" ou "quase sempre" de autoridade para tomar decisões.

\section{Gráfico 2. Orçamento Participativo: padrões correlatos de gastos e atitudes dos cidadãos para explicar resultados de políticas}

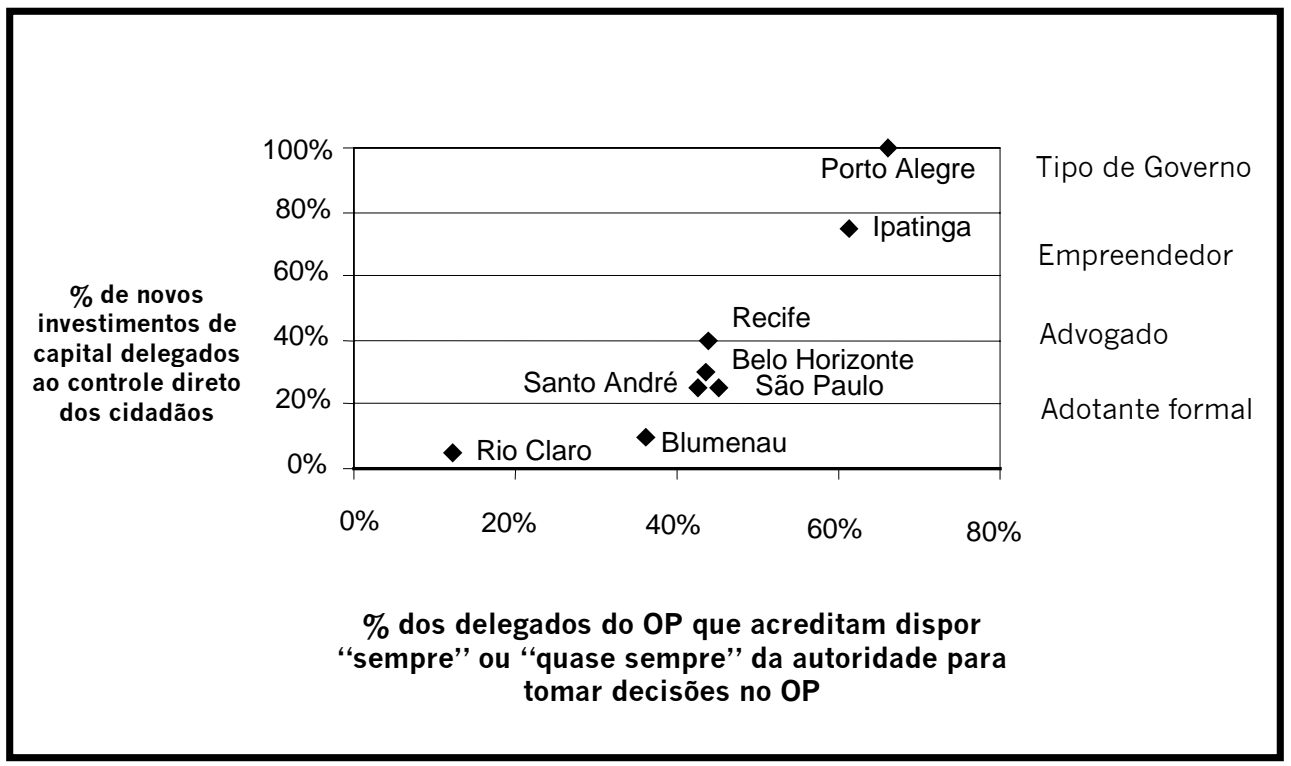

Empreendedores de políticas comandavam dois municípios - Porto Alegre e Ipatinga. Porto Alegre era onde o programa havia surgido, em 1989. Desse momento até 1996, o OP da capital gaúcha foi gerido por dois prefeitos, Olívio Dutra e Tarso Genro, que alcançaram um renome local, nacional e internacional, apoiados no sucesso do programa. O PT venceu quatro eleições sucessivas para prefeito, com o OP no centro de seu programa de governo. Ipatinga havia inaugurado em 1990 uma versão mais modesta do programa, ampliando-o consideravelmente em 1996, na intenção de aproximá-lo do modelo pioneiro de Porto Alegre. O prefeito que o implementou em Ipatinga obteve mais dois mandatos subseqüentes, sendo posteriormente alçado a um assento no Congresso Nacional. Em Porto Alegre e Ipatinga, os líderes do PT construíram suas carreiras políticas dentro do próprio partido e nos respectivos municípios apoiados na promoção do OP (WAMPLER, 2007). 
O percentual dos fundos de novos investimentos de capital que o governo coloca à disposição das decisões dos cidadãos é outra forma de demonstrar o grau em que as administrações delegam a estes sua autoridade. Quanto maior a proporção de recursos delegados diretamente aos cidadãos, tanto maior sua autoridade nos processos decisórios. Em Porto Alegre, $100 \%$ dos fundos de novos investimentos de capital tiveram sua aplicação decidida por delegados do OP (WAMPLER e AVRITZER, 2004; WAMPLER, 2007). Em Ipatinga, esse índice chegou a 50\%. Ademais, a administração municipal pleiteava anualmente fundos estaduais e federais para suplementar os fundos de novos investimentos de capital, o que significa que cerca de $75 \%$ desses fundos foram decididos no âmbito do programa (WAMPLER, 2007).

No outro extremo do espectro estão Blumenau e Rio Claro, que merecem a classificação de adotantes formais, tendo sido o programa iniciado em 1997 em ambos os municípios. Em Blumenau, o PT elegeu prefeito em 1996, o persuadiu a adotar o programa, mas a administração dedicou poucos recursos e reduzida energia à sua implementação. Em Rio Claro, o prefeito era um reformista do Partido Verde, que adotou o OP, mas dedicou mais de seu tempo, energia e recurso a outras políticas. O prefeito aparentemente adotou o programa a reboque da pressão de ativistas da sociedade civil e como forma de apelar à classe média local, interessada em programas de "boa governança" (TEIXEIRA e ALBUQUERQUE, 2005).

O nível de gastos com novos investimentos de capital negociados no âmbito do OP corresponde claramente à crença dos entrevistados de que dispõem de reduzida autoridade. Em Blumenau, o prefeito permitiu que os cidadãos negociassem menos de $15 \%$ dos novos gastos de investimento (WAMPLER, 2007). Em Rio Claro, essa margem sequer alcançou 5\% (TEIXEIRA e ALBUQUERQUE, 2005). Esses números sugerem que os respectivos prefeitos não estavam interessados em assumir os riscos políticos necessários para criar programas de OP vigorosos. Os prefeitos de Blumenau e Rio Claro não delegaram muito de sua autoridade aos cidadãos para assegurar o sucesso do programa porque isso não era decisivo para alcançar seus objetivos políticos. Adotantes formais são os mais refratários a dedicar o tempo, a energia, a vontade política e os recursos necessários para garantir o sucesso do programa. Eles adotam uma boa prática sob a pressão de seu partido político ou então para apelar a grupos específicos de ativistas ou eleitores, mostrando-se de resto pouco propensos a delegar os recursos necessários para produzir resultados similares aos casos mais bem-sucedidos.

A liderança dos quatro casos restantes - Santo André, Belo Horizonte, Recife e São Paulo - pode ser classificada como defensores de políticas. Os administradores de cada um desses municípios estavam dispostos a experimentar novos formatos institucionais que pudessem transformar os processos decisórios 
básicos em suas respectivas prefeituras. Estavam pouco dispostos, contudo, a assumir o risco político de ter cidadãos decidindo diretamente sobre o resultado de importantes políticas públicas. Em lugar disso, os cidadãos obtiveram ali níveis flutuantes de autoridade, com base em critérios pouco claros e cambiantes. Apesar do fato de que todas essas prefeituras se apoiaram na experiência de Porto Alegre, as administrações municipais não se dispuseram a dedicar o tempo, a energia e os recursos necessários para garantir o sucesso de seus programas.

As respostas dos entrevistados em relação à autoridade são todas moderadamente positivas, com cerca de $50 \%$ afirmando que "sempre" ou "quase sempre" puderam exercer autoridade decisória no âmbito do OP. Novamente, as atitudes dos entrevistados guardavam forte correlação com o percentual de recursos que os governos permitiam que os cidadãos negociassem. Em Belo Horizonte, aos cidadãos foi inicialmente concedido o direito de negociar mais de um terço dos novos investimentos de capital (1993/1994), mas em 2003 essa margem já havia recuado para meros 17\% (WAMPLER, 2007). Em Recife, o montante negociado pelos cidadãos havia sido inicialmente de $10 \%$ dos novos investimentos de capital (1995/1996), um índice que subseqüentemente, entre 1997 e 2000, fora novamente reduzido, mas que se ampliou afinal para mais de 50\% em 2001 (WAMPLER, 2007). Em São Paulo, de 2001 a 2004, a margem era de 25 a 35\% dos novos investimentos de capital (WAMPLER, 2007). Em Santo André, o controle dos delegados eleitos para o OP flutuava entre 20 e $50 \%$ dos gastos com novos investimentos de capital, mas as regras institucionais foram estipuladas de maneira a permitir que o governo tivesse poder de veto sobre todas as decisões de políticas públicas (WAMPLER, 2007). A autoridade era apenas parcialmente conferida aos cidadãos, pois os prefeitos não estavam dispostos a arriscar suas carreiras políticas em função de qualquer formato específico de política pública.

Nos quatro municípios administrados por defensores de políticas, verificaram-se níveis moderados de apoio do prefeito à delegação de autoridade decisória aos cidadãos, mas estes sentiam que eram capazes de tomar importantes decisões relativas às políticas públicas. Os dados aqui apresentados são evidentemente mais preliminares que conclusivos, mas sugerem que a promoção das boas práticas pode não produzir os efeitos desejados. Ao contrário, pode ser necessário que ONGs, partidos políticos e cidadãos considerem cuidadosamente que tipo de administração será responsável pela implementação das políticas de boas práticas. Os pioneiros de Porto Alegre e Ipatinga criaram políticas bemsucedidas, em grande medida devido aos recursos alocados por funcionários da administração para a elaboração de novos processos de formulação de políticas públicas. Resulta disso que instituições e indivíduos que defendem a adoção de políticas de boas práticas devem estar mais atentos às implicações envolvidas na promoção de tais políticas. 
WAMPLER, B. A difusão do Orçamento Participativo brasileiro...

\section{Conclusão}

$\mathrm{O}$ artigo enfocou duas questões inter-relacionadas. Primeiro, qual a melhor maneira de explicar a difusão do Orçamento Participativo (OP) entre os maiores municípios brasileiros? O programa se difundiu a partir da experiência inaugural da cidade de Porto Alegre, alcançando mais de 250 municípios em todo o país. A adoção de programas de OP no Brasil foi inicialmente movida pelo sucesso eleitoral e pela disciplina interna do Partido dos Trabalhadores (PT), que resultou no fato de que todos os grandes municípios administrados pelo PT acabassem adotando o programa. O OP foi promovido pelo PT e por organizações da sociedade civil diretamente ligadas ao partido - CUT (Central Única dos Trabalhadores) e o Instituto Cajamar - ou por ONGs próximas a ele - Instituto Pólis e FASE. Uma segunda onda de adoção (de 1997 a 2004) foi dominada por prefeituras de outros partidos, que buscavam obter benefícios gestionários e eleitorais a partir de sua associação a um programa conhecido por sua ênfase na justiça social, na transparência e na participação direta.

O papel ativo do PT na promoção do OP relaciona as duas explicações tradicionais para a difusão de programas de políticas públicas no nível subnacional: eleições, como uma forma de induzir governos a adotar políticas inovadoras, e a utilização de redes de políticas públicas para difundir informações sobre programas de gestão bem-sucedidos. As eleições servem, assim, como um mecanismo de responsabilização, incitando o governo a adotar programas baseados em „boas práticas" da gestão pública. Redes de políticas públicas operam no interior da sociedade civil e da sociedade política, oferecendo informações a ativistas, políticos e governantes eleitos sobre o funcionamento desses programas. A difusão do OP, portanto, indica que o Brasil vem desenvolvendo um ambiente eleitoral e arenas políticas que promovem a adoção de „boas práticas“ de gestão.

A segunda questão enfocada neste artigo se refere ao espectro de resultados alcançados por administrações que adotaram o programa. Esses casos de adoção são meros plágios? Ou são réplicas de boa qualidade? A razão pela qual tais questões são importantes é porque o Banco Mundial e o Hábitat das Nações Unidas agora advogam por todo o planeta a adoção do OP. Ao mesmo tempo em que essa promoção é compreensível, e mesmo louvável, de modo algum é prudente. Com base em dados preliminares, os resultados de políticas públicas produzidos nos casos de adoção parecem ser consideravelmente mais débeis que os obtidos nas experiências originais (ver Gráfico 2). Isso sugere que a fórmula "tamanho único" na abordagem da reforma institucional pode ser contraproducente. Dado o papel crucial desempenhado pelos prefeitos no processo de OP, duas novas categorias . 
defensores de políticas e adotantes formais - foram desenvolvidas para complementar o conceito já familiar de empreendedor de políticas públicas.

Empreendedores de políticas públicas produzem os programas mais bemsucedidos porque o futuro político dos governos implicados se vincula estreitamente ao sucesso desse programa específico. É evidentemente possível que o Banco Mundial e o Habitat das Nações Unidas encontrem políticos empreendedores, dispostos a delegar níveis suficientemente altos de autoridade aos cidadãos em outras cidades, estados e províncias. Em casos de novas adoções, contudo, é mais provável que essas sejam antes as exceções que a norma, pois poucos políticos eleitos se mostrarão dispostos a devolver a autoridade recém-adquirida aos cidadãos que os elegeram. É mais provável que a ampla maioria dos novos casos corresponda à adoção promovida por defensores de políticas e adotantes formais, uma vez que políticos (especialmente em cargos eletivos) não necessariamente se mostrarão propensos a arriscar suas carreiras políticas em nome da delegação de autoridade aos cidadãos.

Defensores de políticas tendem a apoiar certos aspectos do OP, mas não na mesma medida que os empreendedores, pois não estão dispostos a sustentar suas carreiras políticas nesse tipo específico de programa de gestão pública. São com freqüência reformadores dispostos a experimentar novas modalidades de gestão, o que significa que pode haver certos efeitos positivos possibilitados pelo OP. Nesses casos, o OP pode gerar algumas modalidades novas da relação Estado-sociedade, persistindo, contudo, a reprodução de problemáticas formas tradicionais de gestão pública (i. e., clientelismo, cooptação etc.), que marcam a política praticada em muitos dos países em desenvolvimento.

Com freqüência, os programas de OP implementados por adotantes formais produzem resultados que guardam pouca semelhança com aqueles produzidos nos casos de maior sucesso. Sua adoção nesses termos pode causar desilusão entre os cidadãos e entre os formuladores de políticas públicas, a quem haviam sido "vendidos" com base nos benefícios que seriam obtidos se adotassem uma política de "boa prática“, apenas para acabar descobrindo que os resultados são afinal muito mais tímidos. Adotantes formais podem ser persuadidos a adotar o OP por seu partido, por seus aliados na sociedade civil ou por uma organização internacional, mas não há um incentivo forte para que o governo delegue autoridade: é mais provável que, em lugar da participação, o que se fomente entre os cidadãos seja o cinismo.

Essas constatações deveriam ser levadas em conta pelas ONGs nacionais e internacionais que promovem a adoção generalizada das boas práticas. Não se defende aqui que a promoção de boas práticas não deva continuar. No entanto, devemos reduzir consideravelmente nossas expectativas no que diz respeito aos resultados que serão produzidos, assim como reconsiderar os contextos em que 
esses programas vêm sendo adotados. Pode ser valioso para as ONGs e agências internacionais de fomento investir mais tempo na identificação dos governos mais propensos a atuarem como defensores de políticas do que como adotantes formais. Com base nos dados aqui apresentados, parece mais vantajoso promover políticas públicas apoiadas em boas práticas entre os governos mais claramente dispostos a assumir os ônus de agir como defensores de políticas.

\section{Referências Bibliográficas}

ABERS, R. Inventing Local Democracy: Grassroots Politics in Brazil. Boulder: Westview, 2000.

AVRITZER, L. Democracy and the public space in Latin America. Princeton: Princeton University Press, 2002.

BAIOCCHI, G. Militants and Citizens: The Politics of Participatory Democracy in Porto Alegre. Stanford: Stanford University Press, 2005.

BAUMGARTNER, F. \& JONES, B. Agendas and Instability in American Politics. Chicago: University of Chicago Press, 1993.

BERRY, F. S. "Sizing up state policy innovation research“. Policy Studies Journal, vol.22, n³, 1994.

BERRY, F. S. \& BERRY, W. D. "State lottery adoptions as policy innovations: An event history analysis“. American Political Science Review, vol.84, n², 1990.

CABANNES, Y. Municipal finance and participatory budgeting: Base Document. Manuscrito. New York: United Nations, s.d.

COLLIER, D. \& MESSICK, R. E. "Prerequisites versus diffusions: Testing alternative explanations of social security adoption." The American Political Science Review, vol.69, n4, 1975.

ELKINS, Z. Designed by Diffusion: International Networks and the Spread of Democracy. Tese de Doutorado. Department of Political Science, University of California, Berkeley, 2003.

FEDOZZI, L. Orçamento participativo: Reflexões sobre a experiência de Porto. Porto Alegre: Tomo Editorial, 1998.

GENRO, T. Utopia Possível. 2a. ed. Porto Alegre: Artes e Ofícios, 1995.

GUIDRY, J. "Not Just Another Labor Party: The Workers' Party and Democracy in Brazil." Labor Studies Journal, vol.28, $\mathrm{n}^{\circ} 1,2003$. 
HISKEY, J. \& CANACHE, D. "The Demise of One-Party Politics in Mexican Municipal Elections." British Journal of Political Science, vol.35, 2005.

HUNTER, W. From opposition movement to government party: Growth and expansion of the Workers' Party in Brazil. Texto apresentado ao 100o. Encontro Anual da American Political Science Association, Chicago, Illinois. 4 a 6 de setembro de 2004.

KECK, M. E. The Workers' Party and Democratization in Brazil. New Haven: Yale University Press, 1992.

KINGDON, J. W. Agendas, Alternatives, and Public Policies. $2^{\text {nd }}$. edition. New York: Longman, 1995.

MINTROM, M. "Policy entrepreneurs and the diffusion of innovation". American Journal of Political Science, vol. 41, n³, 1997.

MONTERO, A. P. Devolving Democracy? Political Decentralization and the New Brazilian Federalism. In: KINGSTONE, P. R. \& POWER, T.J. (eds.). Democratic Brazil: Actors, Institutions, and Processes. Pittsburgh: University of Pittsburgh Press, 2000.

MONTERO, A. \& SAMUELS, D. Decentralization and democracy in Latin America. Notre Dame: University of Notre Dame Press, 2004.

NYLEN, W R. Participatory Democracy versus Elitist Democracy: Lessons from Brazil. New York: Palgrave Macmillan, 2003.

PIRES, V. "Limites e Pontencialidades do Orçamento Participativo." Revista ABOP (Associação Brasileira de Orçamento Público), vol. 43, n43, 2002.

RIBEIRO TORRES, C. A. \& GRAZIA, G. de. Experiências de Orçamento Participativo no Brasil: Período de 1997 a 2000. São Paulo: Editora Vozes, 2003.

SAMUELS, D. "From Socialism to Social Democracy: Party Organization and the Transformation of the Workers' Party in Brazil." Comparative Political Studies, vol. 37, n9, 2004.

SIMMONS, B. \& ELKINS, Z. "The globalization of liberalization: Policy diffusion in the international political economy." American Political Science Review, vol. 98, nº 1, 2004.

SUGIYAMA, N. Ideology \& Networks: Social Policy Diffusion in Decentralized Brazil. Meeting of the Latin American Studies Association, San Juan, Puerto Rico, 15 a 18 de março de 2006.

TEIXEIRA, A. C. C. e AlBuQUeRQue, M. C. A. Orçamentos Participativos: rojetos politicos, partilha de poder e alcance democrático. São Paulo: Instituto Polis, 2005.

VILLAS BOAS, R. \& TELLES, V. (eds.). Poder local, participação popular, construção da cidadania. São Paulo: Fórum Nacional de Participação Popular nas Administrações Municipais, 1995.

WALKER, J. "The diffusion of innovations among the American States." The American Political Science Review, vol. 63, n³, 1969. 
WAMPLER, B. and AVRITZER, L. "The spread of Participatory Democracy in Brazil: From Radical Democracy to Participatory Good Government. Journal of Latin American Urban Studies, vol. 7, 2006.

. "Participatory publics: Civil society and new institutions in democratic Brazil“. Comparative Politics, vol. 36, n³, 2004.

WAMPLER, B. Participatory Budgeting in Brazil: Contestation, Cooperation, and Accountability. University Park: Pennsylvania State Press, 2007.

WEYLAND, K. Learning from Foreign Models in Latin American Policy Reform. Washington, D.C.: Woodrow Wilson Center Press, 2004.

\section{Entrevistas}

Franciso Assis (Secretário de Política Social, Recife (1997-1999)), data: 8 de setembro de 1998, Recife - PE.

Luciano Fedozzi (Professor e ex-administrador público), data: 25 de maio de 1999, Porto Alegre - RS.

Grazia de Grazia (ONG FASE), data: 24 de outubro de 2003, Brasília - DF.

Salvador Soler (Secretário de Política Social, Recife (1993-1996)), data: 6 de outubro de 1998, Recife - PE.

Renata Villas-Boas (Ex-funcioária do Instituto Polis), data: 6 de maio de 2004, São Paulo SP.

Tradução do original em inglês de Sebastião Nascimento

Recebido para publicação em agosto de 2007. Aprovado para publicação em dezembro de 2007. 